\title{
Functional Outcomes of Reconstruction for Soft Tissue Sarcomas of the Foot and Ankle
}

\author{
by Emmanuel P. Estrella, MD ${ }^{1 \rrbracket}$, Edward HM Wang, MD, MSc ${ }^{1}$, Leo Daniel D. Caro, MD ${ }^{1}$, Vicente G. \\ Castillo, $\mathrm{MD}^{2}$
}

The Foot and Ankle Online Journal 2 (3): 2

Objective: We present the functional outcome of six cases of soft tissue sarcomas of the foot and ankle area treated with limb-sparing surgery and soft tissue reconstruction.

Materials and Methods: Six patients with soft tissue sarcoma of the foot and ankle who were treated with limbsparing surgery and soft tissue reconstructions from 1993 to 2007 were evaluated. On recent follow-up, patients function were scored using a Functional Evaluation Scoring System.

Results: There were three males and three females with an average age of 36.3 years (range, 11-56 years) at the time of surgery. The mean follow-up period was 49 months (range: 4-91 months). The average size of the soft tissue defect was $124.3 \mathrm{~cm}^{2}$ (range, 48-182 $\mathrm{cm}^{2}$ ). All flaps survived. As of final evaluation, three patients are alive without evidence of disease, two patients are alive with evidence of disease and one patient died of disease. The average Enneking Functional Score for the six patients was 92.8\%.

Conclusion: Limb-sparing surgery and soft tissue reconstruction for foot and ankle sarcomas can provide good functional outcomes and will continue to play an important role in the management of these tumors.

Key Words: Sarcoma, foot and ankle, soft tissue reconstruction

S oft tissue sarcomas of the foot and ankle continue to pose a limb and life-threatening disease. In the past, amputation was the resulting outcome when sarcomas of the limb were diagnosed. Advances in reconstructive and limbsparing surgical techniques have given patients with soft tissue sarcomas of the extremity another option of treatment besides amputation.

Corresponding Author: Emmanuel P. Estrella, MD

Department of Orthopedics, University of the Philippines-College of Medicine, Philippine General Hospital, Manila Philippines 1000.

Tel. No. (632) 5242203

Fax No. (632) 5260149

Email Add: estee96@yahoo.com

${ }^{1}$ Consultant, Department of Orthopedics, University of the PhilippinesCollege of Medicine, Philippine General Hospital, Manila, Philippines

${ }^{2}$ Consultant, Department of Surgery, University of the Philippines-College of

Medicine, Philippine General Hospital, Manila, Philippines
The treatment combination of wide resection, adjuvant chemotherapy or radiotherapy and reconstructive surgery has been reported to not increase the incidence of local recurrence, metastasis, or mortality. ${ }^{1,2,3}$

The foot and ankle is a common location where there is usually a soft tissue defect after sarcoma resection. This is an area difficult to reconstruct because of its unique anatomy and paucity of soft tissues. ${ }^{4}$ Various soft tissue reconstructions are described to cover foot and ankle defects either due to trauma or tumor resection. . $^{5,8,9,10}$ 


\begin{tabular}{|c|c|c|c|c|c|c|}
\hline SCORE & PAIN & $\overline{\text { FUNCTION }}$ & EMOTIONAL & $\begin{array}{c}\text { HAND } \\
\text { POSITIONING }\end{array}$ & $\begin{array}{c}\text { MANULA } \\
\text { DEXTERITY }\end{array}$ & $\begin{array}{l}\text { LIFTING } \\
\text { ABILITY }\end{array}$ \\
\hline 5 & No pain & No restriction & Enthused & Unlimited & Unlimited & Normal load \\
\hline 4 & Intermediate & Intermediate & Intermediate & Intermediate & Intermediate & Intermediate \\
\hline 3 & Modest/Non-disabling & $\begin{array}{l}\text { Recreational } \\
\text { restriction }\end{array}$ & Satisfied & $\begin{array}{c}\text { Not above shoulder or } \\
\text { no/Prosupination }\end{array}$ & $\begin{array}{l}\text { Loss of fine } \\
\text { movements }\end{array}$ & Limited \\
\hline 2 & Intermediate & Intermediate & Intermediate & Intermediate & Intermediate & Intermediate \\
\hline 1 & Moderate/Disabling & Partial restriction & Accepts & Not above waist & Cannot pinch & Helping only \\
\hline 0 & Severe disabling & Total restriction & Dislikes & None & Cannot grasp & Cannot help \\
\hline
\end{tabular}

\begin{tabular}{|c|c|c|c|c|c|c|c|}
\hline$\overline{\text { SCORE }}$ & PAIN & FUNCTION & EMOTIONAL & SUPPORTS & WALKING & GAIT & Final Patient \\
\hline 5 & No pain & No restriction & Enthused & None & Unlimited & Normal & Score of \\
\hline 4 & Intermediate & Intermediate & Intermediate & Intermediate & Intermediate & Intermediate & FUNCTIONAL \\
\hline 3 & Modest/Non-disabling & $\begin{array}{l}\text { Recreational } \\
\text { restriction }\end{array}$ & Satisfied & Brace & Limited & Minor cosmetic & EVALUATION \\
\hline 2 & Intermediate & Intermediate & Intermediate & Intermediate & Intermediate & Intermediate & \\
\hline 1 & Moderate/Disabling & Partial restriction & Accepts & $\begin{array}{l}\text { One cane or } \\
\text { crutch }\end{array}$ & Inside only & Major cosmetic & \\
\hline 0 & Severe disabling & Total restriction & Dislikes & $\begin{array}{l}\text { Two canes or } \\
\text { crutches }\end{array}$ & Not independent & Major handicap & \\
\hline $\begin{array}{l}\text { Patient } \\
\text { score }\end{array}$ & & & & & & & \\
\hline
\end{tabular}

Table 1 The Revised Musculoskeletal Tumor Society Rating Scale. (Upper extremity-top, Lower extremity-bottom)

Coverage of these defects should be able to withstand the mechanical stress of weight bearing, as well as to tolerate postoperative chemotherapy or radiotherapy. Local and systemic control and overall function of the individual should also be evaluated after sarcoma surgery.

The objective of this article is to present the functional outcome of six cases of soft tissue sarcoma of the foot and ankle treated with limb-sparing surgery and soft tissue reconstruction.

\section{Patient and Methods}

A retrospective review of all soft tissue sarcomas of the foot and ankle treated by limb-sparing surgery, chemotherapy or radiotherapy, and soft tissue reconstruction from 1993 to 2007 was undertaken at the Department of Orthopedics, University of the Philippines-College of Medicine, Philippine General Hospital, Manila, Philippines. Inclusion criteria included all patients with a histologic diagnosis of soft tissue malignant tumor of the foot and ankle area who had limb salvage surgery. 


\begin{tabular}{|c|c|c|c|c|c|c|c|c|}
\hline $\begin{array}{l}\text { Patient } \\
\text { No. }\end{array}$ & $\begin{array}{c}\text { Age } \\
\text { (years) }\end{array}$ & Sex & $\begin{array}{l}\text { Tumor } \\
\text { Location }\end{array}$ & Tumor Type & $\begin{array}{l}\text { Size of } \\
\text { Defect } \\
\left(\mathrm{cm}^{2}\right)\end{array}$ & $\begin{array}{l}\text { Reconstructive } \\
\text { Procedure }\end{array}$ & $\begin{array}{l}\text { Follow- } \\
\text { up } \\
\text { (months) }\end{array}$ & $\begin{array}{c}\text { Functional Score } \\
(\%)\end{array}$ \\
\hline 1 & 11 & M & $\begin{array}{l}\text { Medial aspect } \\
\text { forefoot }\end{array}$ & $\begin{array}{c}\text { Malignant } \\
\text { Peripheral } \\
\text { Nerve Sheath } \\
\text { Tumor } \\
\end{array}$ & $\begin{array}{c}(6 \times 8 \mathrm{~cm}) \\
48 \mathrm{~cm}^{2}\end{array}$ & $\begin{array}{l}\text { Cross-leg flap } \\
\text { (AWED) }\end{array}$ & 91 & $100 \%$ \\
\hline 2 & 56 & M & Lateral Heel & $\begin{array}{c}\text { High Grade } \\
\text { Liposarcoma }\end{array}$ & $\begin{array}{c}(26 \times 7 \mathrm{~cm}) \\
182 \mathrm{~cm}^{2}\end{array}$ & $\begin{array}{c}\text { Rectus } \\
\text { Abdominis } \\
\text { Free Flap } \\
\text { (AWED) }\end{array}$ & 67 & $96.7 \%$ \\
\hline 3 & 21 & $\mathrm{~F}$ & $\begin{array}{c}\text { Weight- } \\
\text { bearing Heel }\end{array}$ & $\begin{array}{l}\text { Clear Cell } \\
\text { Sarcoma }\end{array}$ & $\begin{array}{c}(9 \times 7 \mathrm{~cm}) \\
63 \mathrm{~cm}^{2}\end{array}$ & $\begin{array}{l}\text { Reverse Sural } \\
\text { Artery Flap } \\
\text { (DOD) }\end{array}$ & 60 & $93.3 \%$ \\
\hline 4 & 40 & $\mathrm{~F}$ & $\begin{array}{l}\text { Medial to } \\
\text { Lateral Heel }\end{array}$ & Fibrosarcoma & $\begin{array}{c}(12 \times 13 \\
\mathrm{cm}) \\
156 \mathrm{~cm}^{2}\end{array}$ & $\begin{array}{c}\text { Reverse Sural } \\
\text { Artery Flap }\end{array}$ & 56 & $90 \%$ \\
\hline 5 & 43 & $\mathrm{~F}$ & Medial Ankle & $\begin{array}{l}\text { Synovial } \\
\text { Sarcoma }\end{array}$ & $\begin{array}{c}(12 \times 15 \\
\mathrm{cm}) \\
180 \mathrm{~cm} 2\end{array}$ & $\begin{array}{c}\text { Reverse Sural } \\
\text { Artery Flap }\end{array}$ & 17 & $87 \%$ \\
\hline 6 & 47 & $\mathrm{M}$ & $\begin{array}{l}\text { Medial Mid } \\
\text { foot }\end{array}$ & $\begin{array}{c}\text { Malignant } \\
\text { Fibrous } \\
\text { Histiocytoma }\end{array}$ & $\begin{array}{c}(9 \times 13 \mathrm{~cm}) \\
117 \mathrm{~cm} 2\end{array}$ & $\begin{array}{c}\text { Reverse Sural } \\
\text { Artery Flap }\end{array}$ & 4 & $90 \%$ \\
\hline Average & $\begin{array}{c}36.3 \\
(11-56 \\
\text { years })\end{array}$ & & & & $124.3 \mathrm{~cm} 2$ & & $\begin{array}{c}49.2(4- \\
91 \\
\text { months) }\end{array}$ & $92.8 \%$ \\
\hline
\end{tabular}

Table 2 Pertinent data on the six patients.

Tumor location, size of defect, reconstructive procedures, histological diagnosis and functional outcome were all critically evaluated. Each patient was contacted for follow-up and was evaluated using The Functional Evaluation of Reconstructive Procedures after Surgical Treatment of Tumors of the Musculoskeletal System for the upper and lower extremity. (Table 1$)^{11}$ Specific numerical values of 0 to 5 were assigned for each factor, based on established criteria and are equated with certain levels of achievement or performance. Each score was presented as a percentage of the total.

\section{The Functional Evaluation of Reconstructive Procedures: Definition of Terms}

Pain: The value for pain is determined by the amount and effect of pain on functional activities. Required information is the medication used by the patient for pain relief.

Function: The value for function is determined by the restriction in activities. The required data are the pretreatment occupation and the degree of occupational disability.

Emotional Acceptance: The value for emotional acceptance is determined by the patients' emotional reaction to or perception of the functional result. 


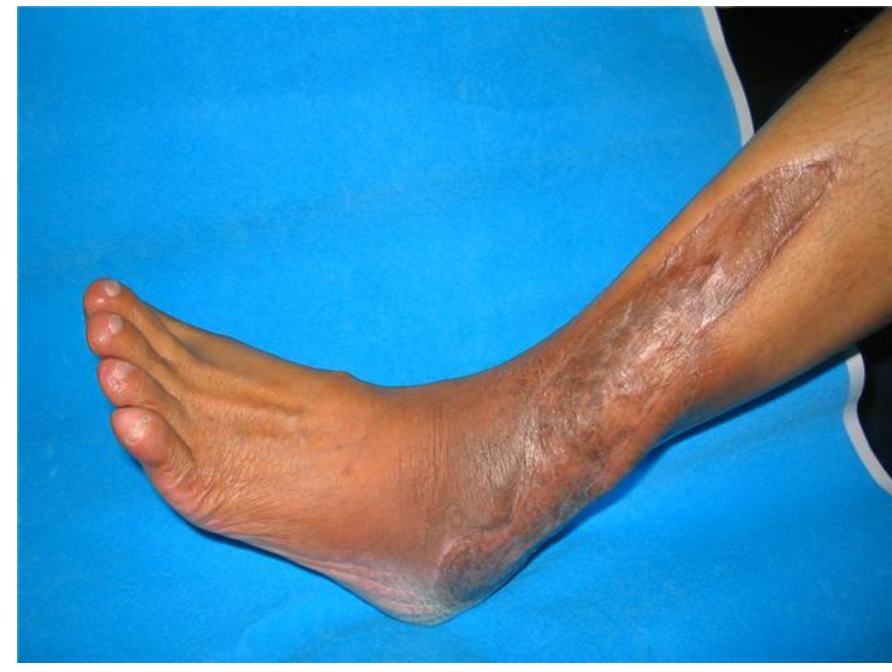

Figure 1 Case no. 2. This is a late post-operative view of a 56 year-old male after wide resection of a liposarcoma of the ankle region at 19 months after rectus abdominis free muscle flap. The flap remained stable. The patient underwent chemotherapy for pulmonary nodules with a decrease in the number of nodules.

Support. The value for support is determined by the use of external support to compensate for weakness and instability as they affect standing or walking. The required data are the type of support and the frequency of use.

Walking Ability: The value for walking ability is determined by the limitations on walking imposed by the procedure. The required data are the walking distance and limitations in type (inside/outside, uphill, stairs, etc.).

Gait. The value for gait is determined by the presence or absence of gait alterations and its effect on restrictions or function. The required data are the type of gait abnormality and resultant restrictions or deformity.

\section{Results}

From 2001 - 2007, we had a total of six patients with soft tissue sarcoma of the foot and ankle area requiring soft tissue reconstruction after tumor resection.

(C) The Foot and Ankle Online Journal, 2009
All six patients were treated with wide resection, soft tissue reconstruction and adjuvant chemotherapy or radiotherapy. There were three males and three females. The mean age was 36.3 years at the time of the surgery (range, 11 - 56 years). The mean followup period was 49 months (range, 4 - 91 months). All soft tissue reconstructions were done at the time of tumor resection. We had one free flap, four reverse pedicle flaps and one cross leg flap. All flaps survived. The cross leg flap was released after two weeks and was uneventful. All patients are now ambulating independently. The mean time from surgery to independent ambulation was 12.5 weeks (range, 2 - 24 weeks). Pertinent data for each patient is summarized in Table 2.

Three patients (patient no. 1, 4 and 6) had previous resections. As of latest follow-up, five patients are alive. Three are alive without evidence of disease, two are alive with evidence of disease, and one died from disease. There were no local recurrences in five patients. Two patients (no. 1 and 2) developed pulmonary nodules after tumor resection. Both are alive with evidence of disease and recieved chemotherapy with a decrease in the number of pulmonary nodules for both. Another patient (no. 3) had a recurrence on the same extremity where another wide resection was done and a soleus flap was used to cover the defect on the anterior leg. The patient died of disease at 60 months after sural flap.

\section{Case Reports}

\section{Case \#2}

A 56 year-old male presented with an enlarging mass at the lateral aspect of the left heel. He was initially diagnosed to have gouty arthritis. Biopsy showed a high-grade liposarcoma. A wide resection was done and a free rectus abdominis flap was used to cover the soft tissue loss. Three months after the resection and reconstruction, computed tomography (CT) of the chest showed multiple metastatic lesions to the lungs. Patient underwent chemotherapy. The Enneking Functional Score was 29/30. Figure 1 illustrates the late post-operative view at 19 months. (Fig. 1) 


\section{Case \#4}

A 40 year-old female presented with a recurring mass over the medial, posterior and lateral aspect of the non weight-bearing heel. The mass had been resected previously on both the lateral and medial aspects of the ankle by a previous surgeon. Review of slides and repeat biopsy revealed a fibrosarcoma. Wide excision was done. The final defect was $12 \mathrm{~cm} \times 13 \mathrm{~cm}$ (Fig 2A). A reverse sural artery flap was used to cover the defect. Post-operative radiotherapy was uneventful. Independent ambulation was started at 16 weeks. Enneking Functional Score was 27/30. Result at 24 months post-op. (Fig. 2B)

\section{Case \#5}

A 43 year-old female with a fungating mass on the medial aspect of the left ankle was diagnosed to have synovial sarcoma on biopsy (Fig.3A). After a wide resection, a $12 \times 15 \mathrm{~cm}$ soft tissue defect was made. (Fig.3B) The defect was covered with reverse sural flap with medial tibio-talar ligament reconstruction using a plantaris tendon graft. At 17 months followup, there was no recurrence of the mass. (Fig. 3C)

\section{Discussion}

We reviewed six cases of soft tissue sarcoma of the foot and ankle, treated by limb-sparing surgery and soft tissue reconstruction. The standard of treatment for soft tissue sarcoma of the extremity is limbsparing surgery, soft tissue reconstruction, and chemotherapy or radiotherapy. Few studies on soft tissue reconstruction for foot and ankle soft tissue sarcoma have been reported. ${ }^{7,9,12}$ Likewise, few studies have evaluated their results with an established functional measurement outcome scale. ${ }^{12}$ In this small series of four patients with foot and ankle sarcoma treated with limb-sparing surgery and soft tissue reconstruction, we presented the functional outcome of these patients using a standardized outcome measurement scale.

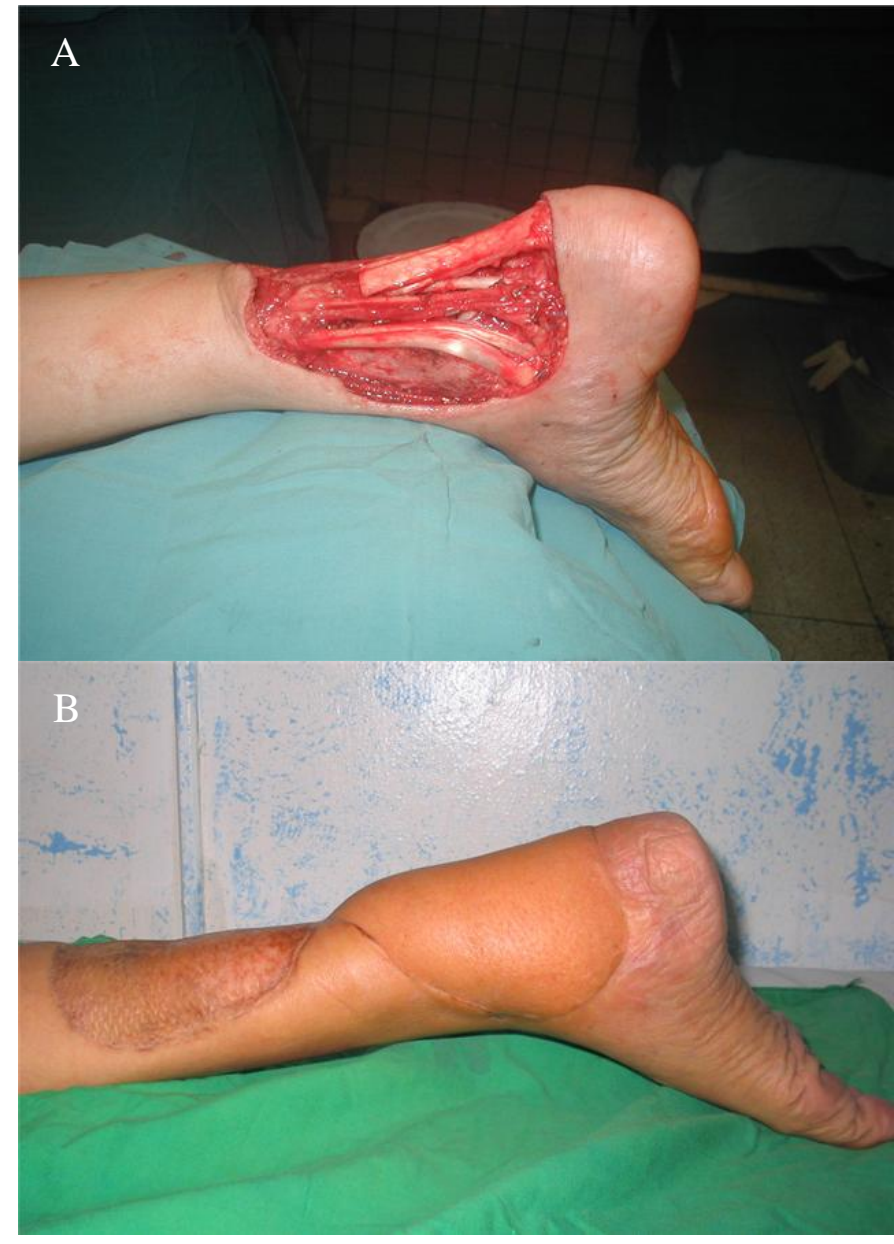

Figures 2A and 2B Case no.4. A 40 year-old female presented with a recurring mass over the ankle area. After wide excision, the final defect was $12 \times 13 \mathrm{~cm}$. Histopathology showed a fibrosarcoma. (A) The sural flap at 48 months after coverage. The flap remained stable. (B)

Flap choices for soft tissue reconstruction after tumor ablation are mainly dependent on what is available, what is needed or on the experience of the reconstructive surgeon. Ideally, the same type of tissue should be replaced during reconstruction. Local tissues give the advantage of near tissue typing and avoidance of lengthy microvascular procedures. However, the limited size and arc of rotation precludes their practical use. 


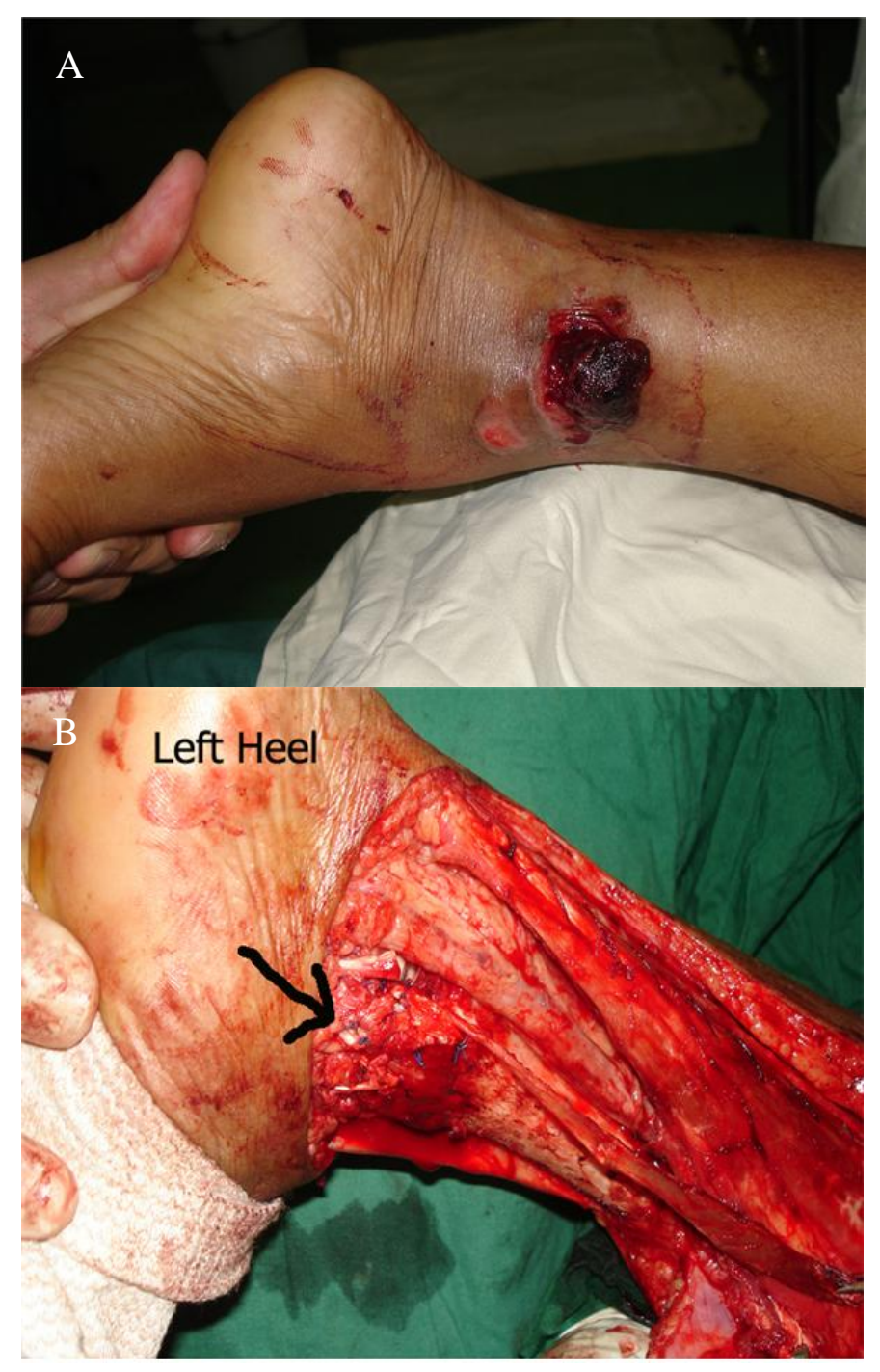

Distant flaps are more often required to overcome these limitations. ${ }^{4} \quad$ Langstein, et al., ${ }^{7}$ reported that free flaps help facilitate limb salvage and that they help preserve meaningful limb function in patients who undergo resection of soft tissue malignancies of the foot. It is possible that the choice of flap is quite different between defects from tumor excision and from traumatic defects. This is because in the event that there would be a local recurrence, reverse pedicled flaps would have increased the contamination of the extremity.

In the case of a reverse sural artery flap, the next surgery that the patient will undergo would probably a below knee amputation in order to have a wider margin of resection.

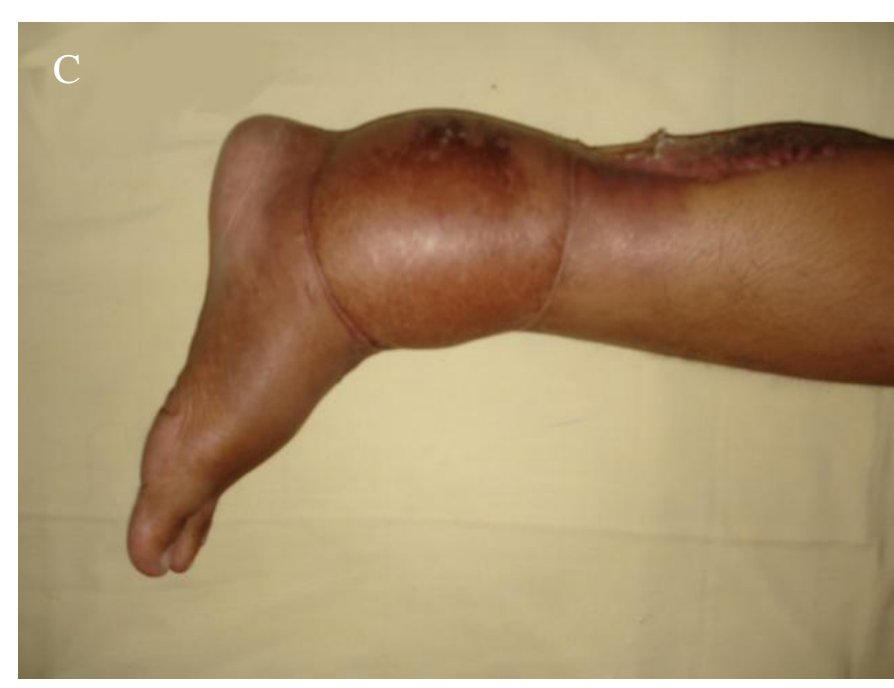

Figures 3A, 3B and 3C Case no. 5. A 43 year-old female presented with a fungating mass on the medial aspect of the right ankle. Biopsy showed a synovial sarcoma. (A) After a wide resection, the medial tibiotalar ligament was excised together with the mass and a defect of $12 \times 15 \mathrm{~cm}$ was evident. The ligament was reconstructed using a plantaris tendon free graft (black arrow). (B) The reverse flap remained stable at 18 months and there was no recurrence of the tumor. (C)

This is one of the reasons why free flaps have become popular choices for foot and ankle coverage after tumor resection. ${ }^{7,12}$ Reverse sural artery flaps are extremely useful and do not need microsurgical anastomosis of vessels. Among the disadvantages of this flap is donor site morbidity, paresthesias on the lateral aspect of the foot, painful neuromas if the sural nerve stump is not buried properly and in some cases, bulkiness of the flap. On the other hand, the sural flap is easier to harvest, has a shorter operative time and can cover a relatively mid-sized defect.

These studies, however, used only independent ambulation as a measure of the functional outcome of their reconstructions. Serletti, et al., ${ }^{12}$ evaluated their results with a standard outcome measure. 
The present study made use of a standardized functional outcome measurement scale to evaluate reconstructive procedures done on the foot and ankle area after tumor resection. Although the overall scores of our patients are high, the only complaint was the deformity due to early physeal closure and the skin graft donor site of the reconstructive procedure. Serletti, et al., ${ }^{12}$ had a similar Functional Outcome Measurement scale and found no difference between pedicled and free flaps in soft tissue reconstruction after tumor excision. However, they tend to favor free flaps to avoid further dissection of the recipient site, and to add vascularity on the already compromised recipient bed.

In summary, successful tumor excision with subsequent reconstructive surgery of foot and ankle sarcomas continues to challenge both the tumor and the reconstructive surgeon.

Careful planning of reconstructive options from the most simple to the more complex should be within the armamentarium of the reconstructive surgeons expertise. We believe that the simplest reconstructive method is still the best technique that will likely produce the best outcome. There will always be instances where a more complex reconstruction will be needed, and with the advances in microsurgery, we are now able to reconstruct larger defects and able to restore function after tumor ablation. By using a standardized functional outcomes assessment for evaluation, we can now redefine our reconstructive options that will best suit our patients in order to produce the best possible results.

\section{References}

1. Lindberg RD, Martin RG, Romsdahl MM, Barkley HT, Jr. Conservative surgery and postoperative radiotherapy in 300 adults with soft tissue sarcomas. Cancer. 47(10): 2391 - 2397, 1981

2. Talbert ML, Zagars GK, Sherman NE, Romsdahl MM. Conservative surgery and radiation therapy for soft tissue sarcoma of the wrist, hand, ankle, and foot. Cancer 66 (12): $2482-2491.1990$

3. Wexler AM, Eilber FR, Miller TA. Therapeutic and functional results of limb salvage to treat sarcomas of the forearm and hand. J. Hand Surg. 13A: 292 - 296, 1988.

4. Clark N, Sherman R. Soft-tissue Reconstruction of the Foot and Ankle. Orthopedic Clinics of North America. 24 (3): 489 503, 1993.

5. Goldberg JA, Adkins RN, Tsai TM. Microvascular reconstruction of the foot: Weight-bearing patterns, gait analysis, and long-term follow-up. Plast. Reconstr. Surg 92 (5): $904-910,1993$.

6. Hidalgo DA, Disa JJ, Cordiero PG, Hu QY. A Review of 716 consecutive free flaps for oncologic surgical defects: Refinement in donor-site selection and technique. Plast. Reconstr. Surg 102 (3): $722-732,1998$.

7. Langstein HN, Chang DW, Miller MJ, Evans GR, Reece GP, Kroll SS, Robb GL. Limb Salvage for soft-tissue malignancies of the foot: an Evaluation of free-tissue transfer. Plast. Reconstr. Surg 109 (1): 152 - 159, 2002.

8. Potparić Z and Rajačić N. Long-term results of weightbearing foot reconstruction with non-innervated and innervated free flaps. Br J Plast Surg 50: 176 - 181, 1997.

9. Reath DB, Taylor JW. The segmental rectus abdominis free flap for ankle and foot reconstruction. Plast Reconstr Surg 88 (5): $824-828,1991$.

10. Weinzweig N, Davies BW. Foot and ankle reconstruction using the radial forearm flap: A review of 25 cases. Plast Reconstr Surg 102 (6): 1999 - 2005, 1998.

11. Enneking F, Dunham W, Gebhardt MC. A system for the functional evaluation of reconstructive procedures after surgical treatment of tumors of the musculoskeletal system. Clin. Orthop 286: 241 - 246, 1993.

12. Serletti, JM, Carras AJ, O'Keefe, RJ, Rosier RN. Functional Outcome after soft-tissue reconstruction for limb salvage after sarcoma surgery. Plast Reconstr Surg 102 (5): 1576 - 1583, 1998. 